\section{Vietnam Journal of Agricultural Sciences}

\title{
Impacts of Culture Conditions on Ligninolytic Enzyme (LIP, MNP, and Lac) Activity of Five Bacterial Strains
}

\section{Pham Hong Hien², Tran Van Mau', Nguyen Thanh Huyen ${ }^{1}$, Tran Thi Dao', Nguyen Van Giang ${ }^{1}$, Tran Thi Hong Hanh', Nguyen Thi Cam Chau ${ }^{1}$, Nguyen Xuan Canh ${ }^{1}$}

${ }^{1}$ Faculty of Biotechnology, Vietnam National University of Agriculture, Hanoi 131000, Vietnam

${ }^{2}$ Department of Science and International Cooperation, Vietnam Academy of Agricultural Sciences, Hanoi 134000, Vietnam

\begin{abstract}
In this study, with the aim of determining and assessing the influence of several culture conditions on the ligninolytic enzyme ( $\mathrm{LiP}, \mathrm{MnP}$, and Lac) activity of bacteria, five lignin-degrading bacteria strains were isolated from two different soil samples and cultured on minimum salt medium agar containing alkaline lignin (MSML agar). Among the five isolated strains, DL1 and X3 expressed strong and stable ligninase enzyme activity at various temperature levels $\left(30^{\circ} \mathrm{C}\right.$, $37^{\circ} \mathrm{C}, 50^{\circ} \mathrm{C}$, and $60^{\circ} \mathrm{C}$ ) and were selected for further study. Notably, at $60^{\circ} \mathrm{C}$, the ligninase activity of both strains lasted until the seventh day before decreasing. The effects of the culture medium conditions, namely, carbohydrate sources, nitrogen sources, and $\mathrm{pH}$, on the ligninolytic system illustrated that both $\mathrm{X} 3$ and DL1 were able to generate good enzymatic activity at a $\mathrm{pH}$ range of 3.0 to 7.0. These strains could use various sources of carbohydrates and nitrogen, derived from glucose, lactose, peptone, meat extract, and yeast extract. In addition, the analyses of biochemical characteristics revealed that X3 was capable of hydrolyzing starch and cellulose, while DL1 was not. Therefore, the results of this study suggested the potential of applying selected lignin-degrading bacterial strains on lignin treatments of agricultural wastes.
\end{abstract}

\section{Keywords}

ligninolytic enzymes, ligninase, lignin peroxidase, manganese peroxidase, laccase

\section{Introduction}

Vietnam is a country that has good conditions for agricultural production and has become one of the largest exporters in the world for specific goods such as rice, coffee, cashew seeds, corn, and fruits. The 
production and processing of agricultural products generates millions of tons of residues annually which are various in type and source. Agricultural residues are waste substances that arise from cultivation, animal husbandry, and aquaculture. However, cultivation releases an enormous amount of dry biomass from plants such as rice straw, rice bran, sugarcane bagasse, sawdust, corn stoves, and coconut shells, etc. These residues are comprised of lignocellulose, the most abundant resource of organic material in the world, which is composed of lignin, cellulose, and hemicellulose. Among them, lignin compounds are the hardest to break down for most organisms because of their complex, heterogeneous structure (Wong, 2009).

Lignin is found in all vascular plants to give structural support for the cell walls. Second only to cellulose, lignin is one of the most abundant carbon sources on earth, accounting for $20-35 \%$ of dried-biomass of wood (Wong, 2009). In plant cell walls, lignin is known as the "glue" between different plant polysaccharides such as hemicellulose and cellulose, so it is particularly difficult to separate lignin from the lignocellulose structure, and thereby confers physical strength to the cell wall and by extension, the plant as a whole (Chabannes, 2001). In older trees, the lignin content is higher as the number of wood cells is increased. The structural complexity of lignin, which is an aromatic polymer, makes it one of the most recalcitrant molecules whose breakdown involves multiple biochemical reactions that must take place more or less concurrently. These reactions include cleavage of inter monomeric linkages, demethylations, hydroxylations, sidechain modifications, and aromatic ring fission followed by dissimulation of the aliphatic metabolites produced. The current pretreatment methodologies for lignin degradation utilize energy-intensive processes (high pressure and temperature) and harsh chemical compounds $\left(\mathrm{NaOH}, \mathrm{H}_{2} \mathrm{SO}_{4}\right)$. This collaboration generates unexpected compounds and inefficient processing (Vicuña, 1988). To pass through these issues, some researchers have developed more sustainable techniques such as using ligninolytic enzymes produced by different groups of microorganisms (Magalhães et al., 1996; Singh \& Tripathi, 2007).

In natural conditions, various microorganisms can degrade lignin; among them, fungi are the most potential sources of lignin-degrading enzymes. The most studied fungi are Phanerochaete chrysosporium, Trametes spp., Pleurotus ostreatus, Dichomitus squalens, Lentinula edodes, Irpex lacteus, and Cerrena maxima (Martínez et al., 2009). Actinomycetes, $\alpha$-proteobacteria, and $\gamma$ proteobacteria such as Streptomyces spp., Azospirillum lipoferum, and Bacillus subtilis (Ramachandra et al., 1987; Givaudan et al., 1993; Martins et al., 2002; Niladevi \& Prema, 2005) are the essential bacteria involved in lignin breakdown. These microorganisms possess either oxidative enzymatic systems or ligninolytic enzymes that are involved in the complete degradation of lignin. The three major ligninolytic enzymes are lignin peroxidase (known as ligninase in early publications; LiP; EC 1.11.1.14), manganese peroxidase (MnP; EC 1.11.1.13), and laccase (Lac; EC 1.10.3.2). The features of these enzymes are different based on their microbial sources. The capability of each microorganism to create one or more of these enzymes also varies widely among different microbial groups (Niladevi \& Prema, 2005). In a laboratory setting, microbial culture also plays a key role in the productivity of bacteria. Thus, this study aims to describe the relevant impacts of various culture conditions of the medium on the ligninolytic activity of bacteria.

\section{Materials and methods}

\section{Materials}

The soil samples were collected from the Xuan Lien Natural Conservation Area in Thanh Hoa province and the composting unit of the Research Center For Medicinal Plants (RCMP), National Institute of Medicinal Materials (NIMM), in Hanoi to isolate the bacterial strains that had ligninolytic enzymes.

\section{Methods}

Isolation and screening of lignindegrading bacteria 
Isolation of bacteria was performed using the procedures of Sasikumar et al. (2014). The samples were first dried and milled, and $1 \mathrm{~g}$ of each sample was suspended in $9 \mathrm{~mL}$ sterile distilled water and serially diluted $\left(10^{-1}\right.$ to $\left.10^{-5}\right)$. After serial dilution, $0.1 \mathrm{~mL}$ of solution was removed using a sterile micropipette and plated on minimum salt medium agar containing alkaline lignin (MSML agar): $\mathrm{K}_{2} \mathrm{PO}_{4} 4.55 \mathrm{~g} \mathrm{~L}^{-1}$, $\mathrm{NH}_{4} \mathrm{NO}_{3} 5.00 \mathrm{~g} \mathrm{~L}^{-1}, \mathrm{H}_{3} \mathrm{BO}_{3} 0.5 \mathrm{~g} \mathrm{~L}^{-1}, \mathrm{CaCl}_{2} 0.01$ $\mathrm{g} \mathrm{L}^{-1}, \mathrm{KH}_{2} \mathrm{PO}_{4} 0.53 \mathrm{~g} \mathrm{~L}^{-1}$, trace element solution $1.00 \mathrm{~mL}\left(\mathrm{ZnSO}_{4} .7 \mathrm{H}_{2} \mathrm{O} 2.20 \mathrm{~g} \mathrm{~L}^{-1}\right.$, Mn acetate $0.50 \mathrm{~g} \mathrm{~L}^{-1}, \mathrm{FeCl}_{3} 0.50 \mathrm{~g} \mathrm{~L}^{-1}, \mathrm{CuSO}_{4} .6 \mathrm{H}_{2} \mathrm{O} 0.16 \mathrm{~g}$ $\mathrm{L}^{-1}$, molybdic acid $0.11 \mathrm{~g} \mathrm{~L}^{-1}$, and $\mathrm{Na}_{2}$ EDTA $5.00 \mathrm{~g} \mathrm{~L}^{-1}$ ). The plates were then incubated at $30^{\circ} \mathrm{C}$ for 5-7 days. Three replicates were maintained from each dilution.

Determination of the ligninolytic enzymes (enzyme activity assays)

The supernatant of the broth cultures was centrifuged at $8000 \mathrm{rpm}$ for $10 \mathrm{~min}$ at $4{ }^{\circ} \mathrm{C}$ and served as the enzyme source. Lignin peroxidase activity was estimated by the modified methods of Magalhães et al. (1996). The assay is based on the demethylation of methylene blue as a substrate in the presence of $\mathrm{H}_{2} \mathrm{O}_{2}$. The quantitative assay mixture had a volume of $3.0 \mathrm{~mL}$ and contained $2.2 \mathrm{~mL}$ of the supernatant, $0.1 \mathrm{~mL}$ of $1.2 \mathrm{mM}$ methylene blue, and $0.6 \mathrm{~mL}$ of $0.1 \mathrm{M}$ citrate buffer $(\mathrm{pH} 4.0)$. The reaction was started by the addition of $0.1 \mathrm{~mL}$ of $\mathrm{H}_{2} \mathrm{O}_{2} 3 \%$. The conversion of the dye to Azure $\mathrm{C}$ was monitored by measuring the decrease in absorbance at $664 \mathrm{~nm}$.

The methylene blue reaction can also be used for a visual inspection of the presence of lignin peroxidase in the culture supernatant as a fast qualitative assay (Magalhães et al., 1996). The assay mixture of $2.7 \mathrm{~mL}$ contained $2.2 \mathrm{~mL}$ of the supernatant, $0.1 \mathrm{~mL}$ of $1 \mathrm{mM}$ methylene blue, and $0.3 \mathrm{~mL}$ of $0.1 \mathrm{M}$ citrate buffer ( $\mathrm{pH} 4.0$ ). The oxidative reaction was started by the addition of $0.1 \mathrm{~mL}$ of $\mathrm{H}_{2} \mathrm{O}_{2} 3 \%$. The color that developed in the presence of lignin peroxidase was compared to a blank assay where distilled water was used to replace the supernatant. The color may develop immediately depending on the enzyme concentration.
The MnP activity was assayed by the oxidation of phenol red as a substrate in the presence of hydrogen peroxide according to the modified methodology of Kuwahara et al. (1984). The reaction medium was composed of $500 \mu \mathrm{L}$ of the crude enzyme extract, $25 \mu \mathrm{L}$ of manganese sulfate $(2.0 \mathrm{mM}), 100 \mu \mathrm{L}$ of bovine albumin $(0.5 \% \mathrm{w} / \mathrm{v}), 50 \mu \mathrm{L}$ of hydrogen peroxide (3\%), $500 \mu \mathrm{L}$ of citrate buffer $(0.1 \mathrm{M}, \mathrm{pH} 4.0)$, $100 \mu \mathrm{L}$ of sodium lactate $(0.25 \mathrm{M})$, and $50 \mu \mathrm{L}$ of phenol red $(0.1 \% \mathrm{w} / \mathrm{v})$. The reaction was monitored by measuring the optical density spectrophotometrically at $610 \mathrm{~nm}$.

Lac activity was determined via the oxidation of 2,2'-azino-bis(3ethylbenzthiazoline)-6-sulfonate (Papinutti et al., 2003). The reaction mixture consisted of $0.1 \mathrm{~mL}$ of ABTS $(0.3 \mathrm{mM}), 0.3 \mathrm{~mL}$ of citrate buffer $(0.1 \mathrm{M}, \mathrm{pH} 4.0)$, and $0.6 \mathrm{~mL}$ of the enzyme solution. ABTS oxidation was monitored by the increase in absorbance at $420 \mathrm{~nm}$.

The activity of ligninolytic enzymes (U/L) was calculated using the equation described below (Magalhães et al., 1996).

$$
\frac{\Delta A b s \times 10^{6}}{\varepsilon \times R \times t}
$$

in which: $\triangle A b s$ is the difference between the absorbance at 0 and $5 \mathrm{~min} ; \varepsilon$ is the extinction coefficient of oxidation $\left(\boldsymbol{\varepsilon}_{610}=4460 ; \boldsymbol{\varepsilon}_{420}=36000\right)$; $\mathrm{R}$ is the aliquot of the supernatant $(\mathrm{mL})$; and $\mathrm{t}$ is the reaction time ( $\mathrm{min}$ ).

Investigation of the impact of culture conditions on the ligninase activities of the selected bacteria

The effects of culture temperature and $\mathrm{pH}$ values on the ligninase enzymes of the selected bacteria were analyzed. The strains were cultured on LB (Luria - Bertani) medium with different culture incubation temperature conditions $\left(30^{\circ} \mathrm{C}\right.$, $37^{\circ} \mathrm{C}, 50^{\circ} \mathrm{C}$, and $60^{\circ} \mathrm{C}$ ) with $\mathrm{pH} 7.0$ as the control, and different $\mathrm{pH}$ conditions (3.0, 4.0, 5.0, 6.0, 7.0, 8.0, 9.0, and 10.0 ) with $30^{\circ} \mathrm{C}$ as the control. After $48 \mathrm{~h}$, the broth cultures were measured for enzymatic activities. To test for the ability of temperature tolerance, the strains were cultured at $60^{\circ} \mathrm{C}$ and the ligninolytic enzymes 
were assessed at the beginning of the first day, followed by every two days, and then at the end of the eleventh day.

In order to analyze the effects of nitrogen sources, the chosen strains were cultured at $30^{\circ} \mathrm{C}$ in an incubator on minimal mineral medium $\left(\mathrm{KH}_{2} \mathrm{PO}_{4} 1.36 \mathrm{~g} \mathrm{~L}^{-1}, \mathrm{CaCl}_{2} 0.03 \mathrm{~g} \mathrm{~L}^{-1}, \mathrm{Na}_{2} \mathrm{HPO}_{4}\right.$ $2.13 \mathrm{~g} \mathrm{~L}^{-1}, \mathrm{MgSO}_{4} .7 \mathrm{H}_{2} \mathrm{O} 0.20 \mathrm{~g} \mathrm{~L}^{-1}, \mathrm{FeSO}_{4} .7 \mathrm{H}_{2} \mathrm{O}$ $0.01 \mathrm{~g} \mathrm{~L}^{-1}$, and D-Glucose $10 \mathrm{~g} \mathrm{~L}^{-1}$ ) as a control, which was supplemented with $0.1 \%$ by weight of one of the different nitrogen sources, namely $\mathrm{NaNO}_{3}, \quad \mathrm{NH}_{4} \mathrm{Cl}, \quad \mathrm{NH}_{4} \mathrm{NO}_{3}, \quad\left(\mathrm{NH}_{4}\right)_{2} \mathrm{SO}_{4}$, triammonium citrate, peptone, meat extract, or yeast extract. After 48h, the enzymatic activities of the broth cultures were examined.

To analyze the effects of carbon sources, the selected strains were cultured at $30^{\circ} \mathrm{C}$ in an incubator on basic mineral medium $\left(\left(\mathrm{NH}_{4}\right)_{2} \mathrm{SO}_{4}\right.$ $2.0 \mathrm{~g} \mathrm{~L}^{-1}, \mathrm{MgSO}_{4} .7 \mathrm{H}_{2} \mathrm{O} 0.2 \mathrm{~g} \mathrm{~L}^{-1}, \mathrm{NaH}_{2} \mathrm{PO}_{4} . \mathrm{H}_{2} \mathrm{O}$ $0.5 \mathrm{~g} \mathrm{~L}^{-1}, \mathrm{CaCl}_{2} .2 \mathrm{H}_{2} \mathrm{O} 0.1 \mathrm{~g} \mathrm{~L}^{-1}$, and $\mathrm{K}_{2} \mathrm{HPO}_{4} 0.5$ $\mathrm{g} \mathrm{L}^{-1}$ ) as a control, which was supplemented $1 \%$ $(w / v)$ with one of the various carbohydrate sources, namely, D-Glucose, D-Fructose, maltose, raffinose, rhamnose, lactose, saccharose, dextrin, or starch. After $48 \mathrm{~h}$, the broth cultures were examined for enzymatic activities.

\section{Identification of the biological} characteristics of the selected bacterial strains

The final selected strains were cultured on special mediums at different conditions for studying their biochemical capabilities, namely, the hydrolyzation of starch (on starch agar) and cellulose (on CMC agar), motility (on semisolid nutrient agar), urease activity (on urea agar), citrate utilization (on Simon citrate agar), and catalase activity (on LB agar).

\section{Results and discussion}

\section{Dection of lignin-degrading bacteria from the samples}

Based on the morphological characteristics of the colonies (Figure 1), the colonies that were blue in the center and turned the areas around the colonies light blue were chosen as the strains that had the potential to degrade lignin. Five bacterial strains were isolated and tested by fast qualitative assay (Magalhães et al., 1996) to determine whether or not they had lignin peroxidase activity (Table 1). The results shown in Figure 2 illustrate that all the strains showed LiP activity, and most featured enzymes of ligninase systems, so these strains were used in the next study.

\section{Assessment of the effects of environmental conditions on ligninolytic activity of the selected bacteria}

\section{Effects of temperature}

Microbes have different abilities to adapt to different environmental conditions which affect the metabolism and growth of each species. Investigating various culture factors, especially temperature and $\mathrm{pH}$ conditions, on the growth and development of the five selected strains can reveal their potential to impact the enzyme activities of the bacteria and provide useful information about culture conditions for other research projects. In this research, the effects of temperature levels on the ligninase enzymes of these strains were checked by incubation at temperatures of $30^{\circ} \mathrm{C}$, $37^{\circ} \mathrm{C}, 50^{\circ} \mathrm{C}$, and $60^{\circ} \mathrm{C}$, and then evaluated by qualitative assay for $\mathrm{LiP}$ and quantitative assay for both $\mathrm{MnP}$ and Lac activities. The results showed that all the strains had the capability to tolerate high temperatures $\left(50^{\circ} \mathrm{C}\right.$ and $\left.60^{\circ} \mathrm{C}\right)$ as well as maintain efficient production of all three

Table 1. Five bacterial strain were isolated

\begin{tabular}{cc}
\hline \multicolumn{1}{c}{ Samples } & Strains \\
\hline Soil of Xuan Lien Natural Conservation Area in Thanh Hoa province & XL1 \\
Composting unit of the Research Center for Medicinal Plants & DL1 X1 X2 \\
National Institute of Medicinal Materials & X3 \\
\hline
\end{tabular}




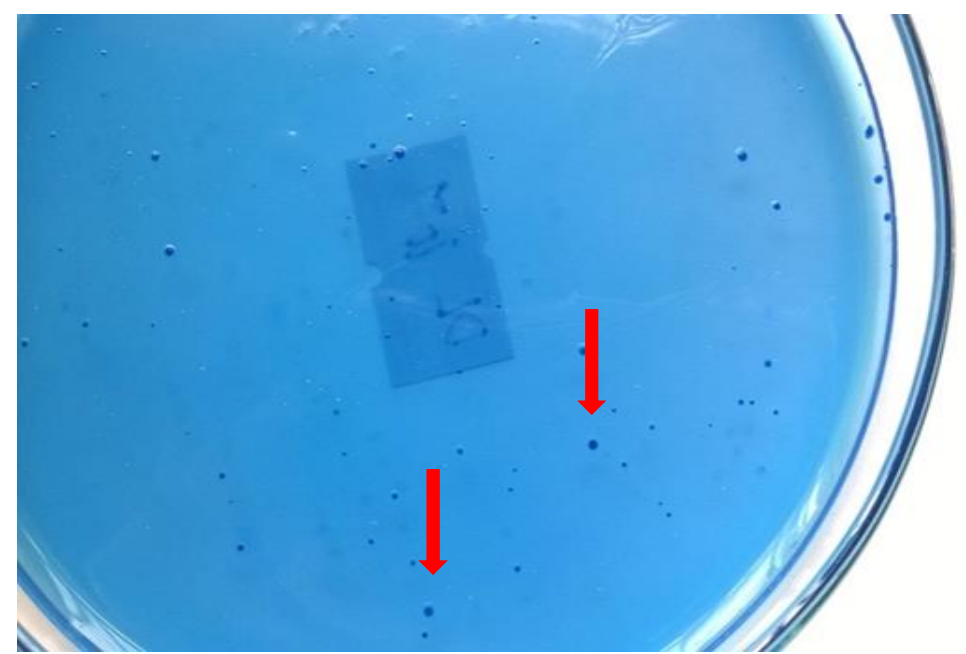

Figure 1. Colonies of the isolated strains on $\mathrm{CMC}$ agar, supplemented with $25 \mathrm{mg} \mathrm{L}^{-1}$ methylene blue Arrows indicate the colonies that were selected as potential lignin-degrading bacteria.

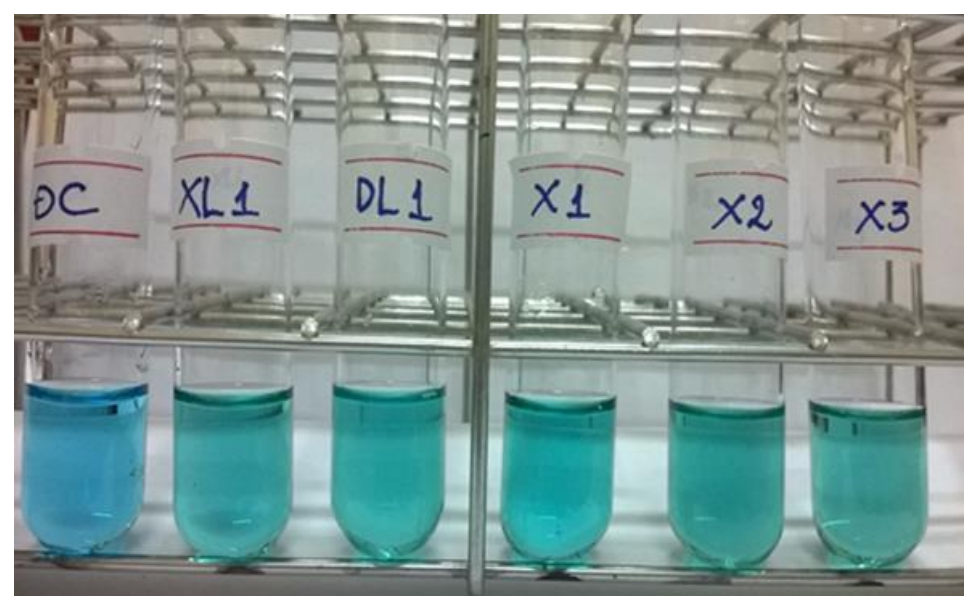

Figure 2. The results of the LiP qualitative assay of the five selected strains Note: The control (EC), XL1, DL1, X1, X2, X3

ligninase enzymes at these temperature levels (Figures 3 and 4). In particular, using visual inspections for the presence of LiP in the culture supernatant as a fast qualitative assay, the LiP activities estimated the representation via the strength of the colors in the reaction tubes (green) compared to the control tube (blue). This color could be developed immediately, depending on the enzyme concentration (Magalhães et al., 1996). According to the organoleptic examination (Figure 3), $37^{\circ} \mathrm{C}$ and $50^{\circ} \mathrm{C}$ were the best temperatures for LiP yield. Simultaneously, the data in Figure 4A demonstrates that MnP production of all five strains increased significantly when the culture temperature level increased. These strains had the highest productivity of $\mathrm{MnP}$ at $60^{\circ} \mathrm{C}$, except $\mathrm{X} 1$ which showed the most prominent product at $50^{\circ} \mathrm{C}$. Of interest, $\mathrm{X} 3$ indicated the highest $\mathrm{MnP}$ activity (122.322 U/L) of all the strains while the MnP of DL1 was relatively proficient and stable at both $50^{\circ} \mathrm{C}(92.107 \mathrm{U} / \mathrm{L})$ and $60^{\circ} \mathrm{C}(92.825 \mathrm{U} / \mathrm{L})$. On the other hand, different from the $\mathrm{MnP}$ activities, Figure 4B illustrates the fluctuations in Lac enzyme yields among the studied strains when cultured at the various temperature conditions. However, two strains, DL1 and X3, showed increases of Lac product following increases of temperature, as the highest Lac activities for X3 and DL1 were $0.565 \mathrm{U} / \mathrm{L}$ and $1.324 \mathrm{U} / \mathrm{L}$, respectively, at $60^{\circ} \mathrm{C}$ incubation.

These data indicated that all five of the studied strains had the potential to endure the 

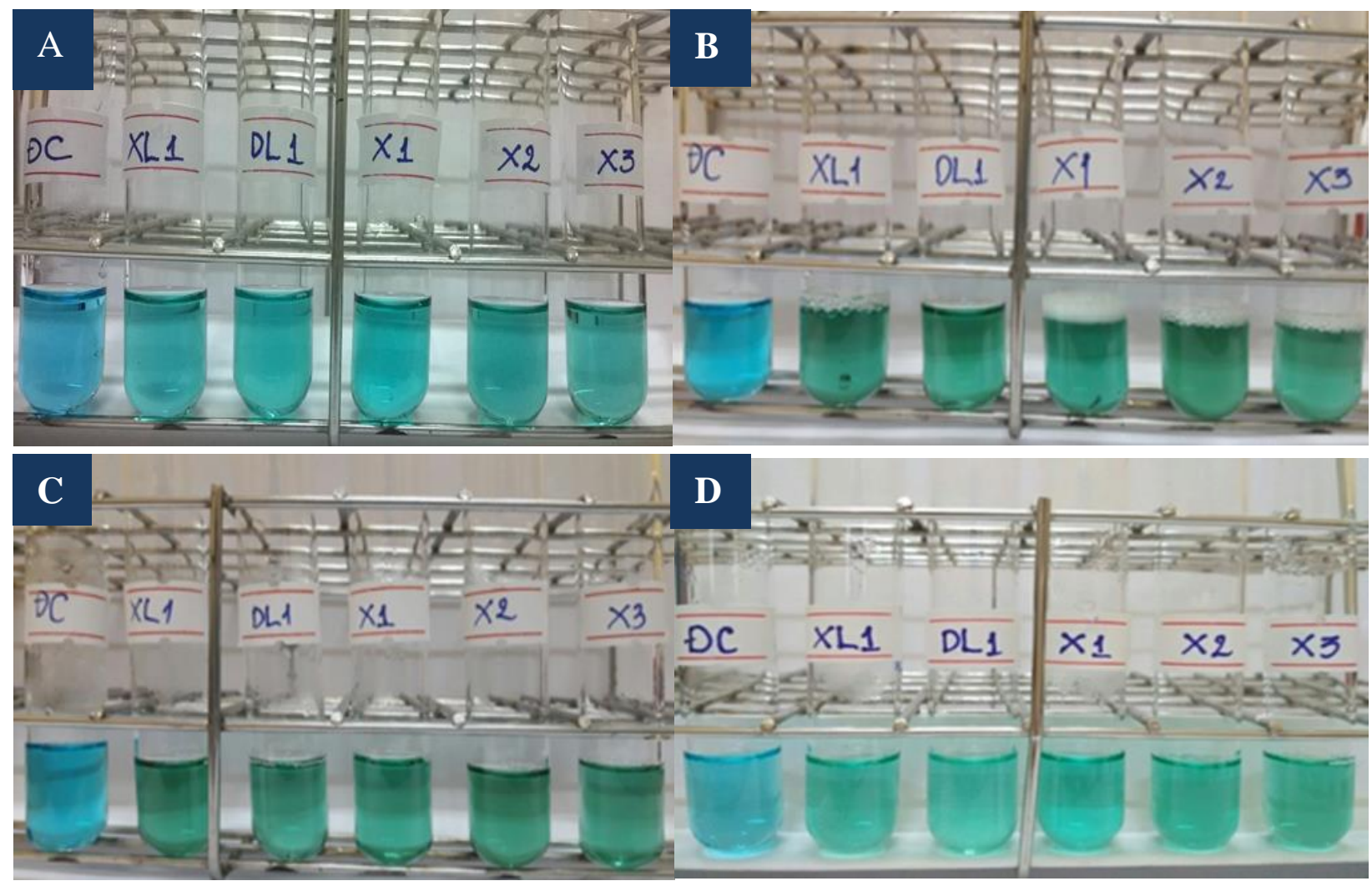

Figure 3. Effects of temperature level $\left(30^{\circ} \mathrm{C}(\mathrm{A}), 37^{\circ} \mathrm{C}(\mathrm{B}), 50^{\circ} \mathrm{C}(\mathrm{C})\right.$, and $\left.60^{\circ} \mathrm{C}(\mathrm{D})\right)$ on the five strains by the LiP qualitative assay
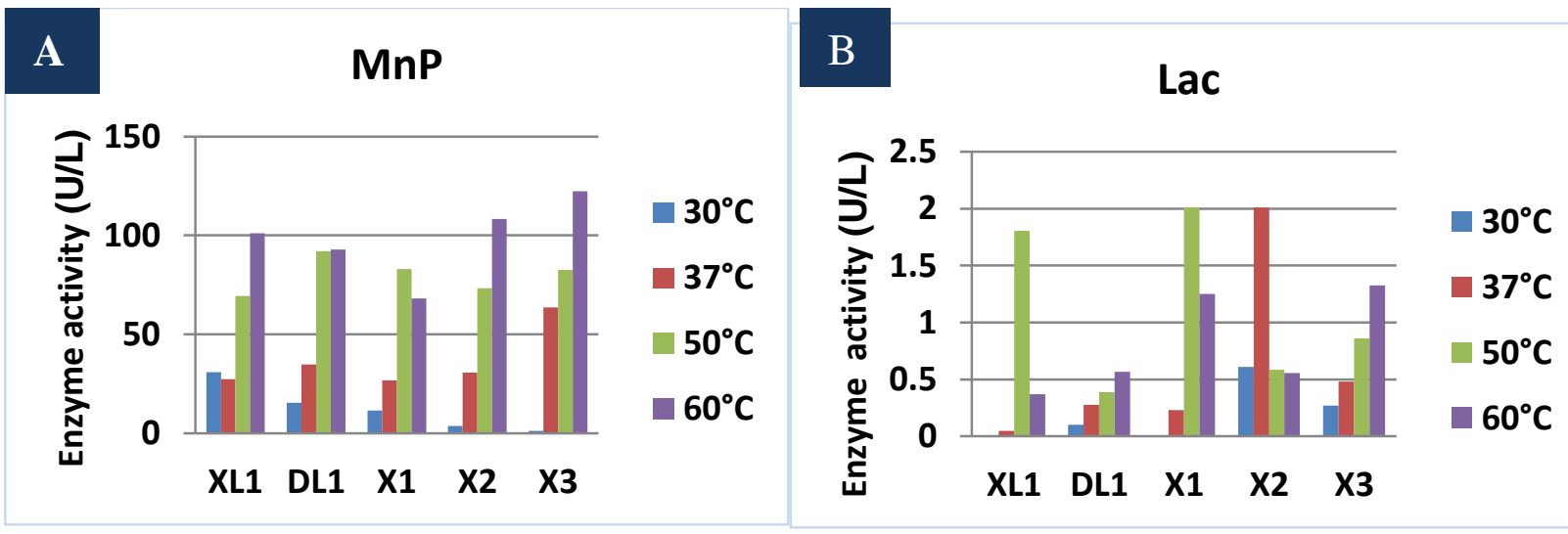

Figure 4. Effects of temperature level $\left(30^{\circ} \mathrm{C}, 37^{\circ} \mathrm{C}, 50^{\circ} \mathrm{C}\right.$, and $\left.60^{\circ} \mathrm{C}\right)$ of the five strains on $\mathrm{MnP}(\mathrm{A})$ and Lac $(\mathrm{B})$ activities by quantitative assay

high-temperature conditions of $60^{\circ} \mathrm{C}$, and the ligninolytic products were represented remarkably and suitable for the aim of microbial applied research on agricultural residues treatment by biopile. Thus, these strains were continuously surveyed to study the impacts of extended incubation at $60^{\circ} \mathrm{C}$ on the ligninase systems by similar qualitative and quantitative methods. For this study, the effects were checked by incubating the five strains at $60^{\circ} \mathrm{C}$ for eleven days and the enzyme production was assessed every two days beginning from the first day. The results presented in Figures 5 and $\mathbf{6}$ show that production of all three ligninase enzymes could be maintained and developed over a long time at $60^{\circ} \mathrm{C}$ (production of LiP lasted to the $9^{\text {th }}$ day for all the strains and was most clearly represented on the $3^{\text {rd }}$ day, Figure 5), especially in X3 and DL1. Interestingly, both X3 and DL1 also had distinctive efficiencies in regards to $\mathrm{MnP}$ yields. 


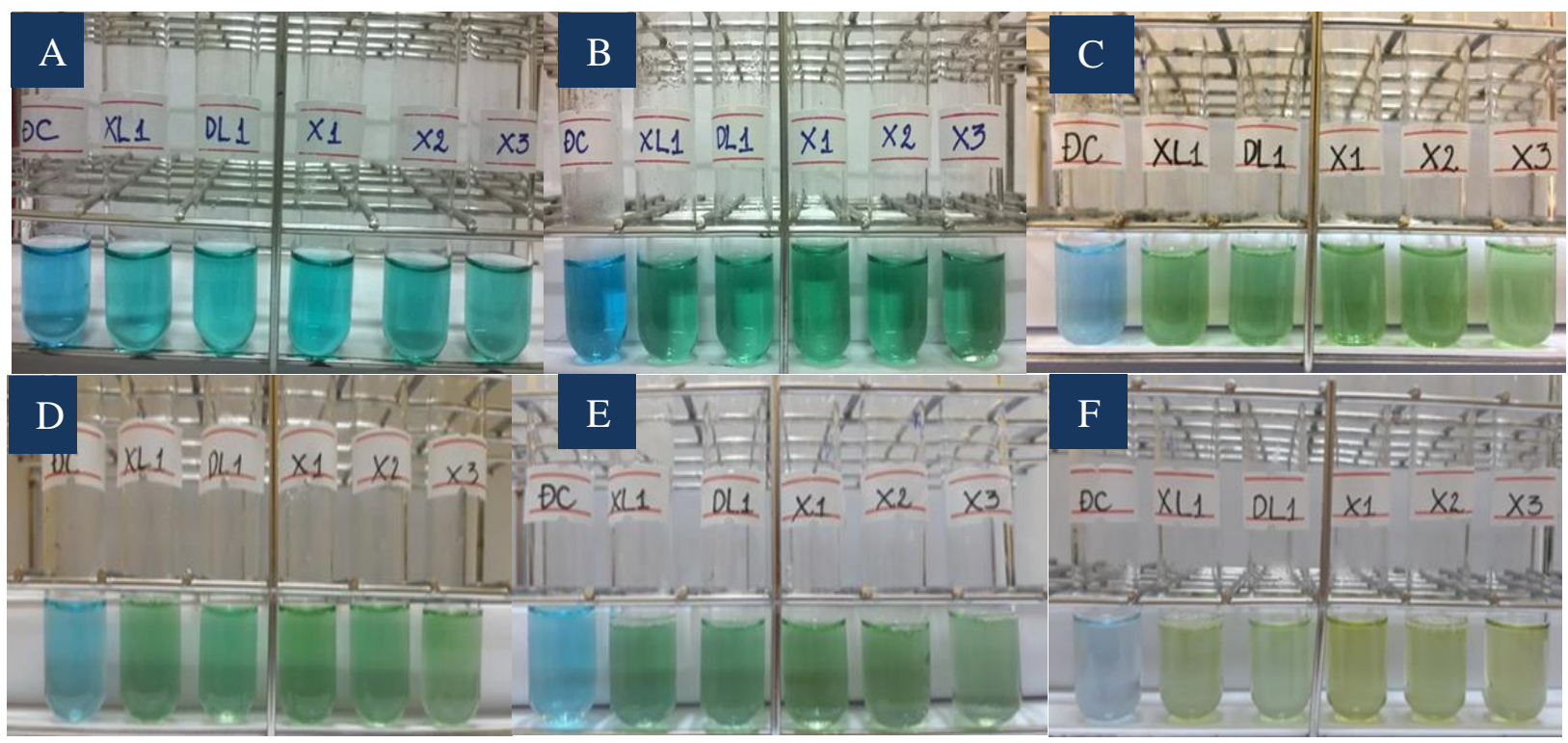

Figure 5. Impacts of culture time in $60^{\circ} \mathrm{C}$ incubation on the LiP activities of the five strains by the LiP qualitative assay on the $1^{\text {st }}$ day $(A), 3^{\text {rd }}$ day $(B), 5^{\text {th }}$ day $(C), 7^{\text {th }}$ day $(D), 9^{\text {th }}$ day $(E)$, and $11^{\text {th }}$ day $(F)$

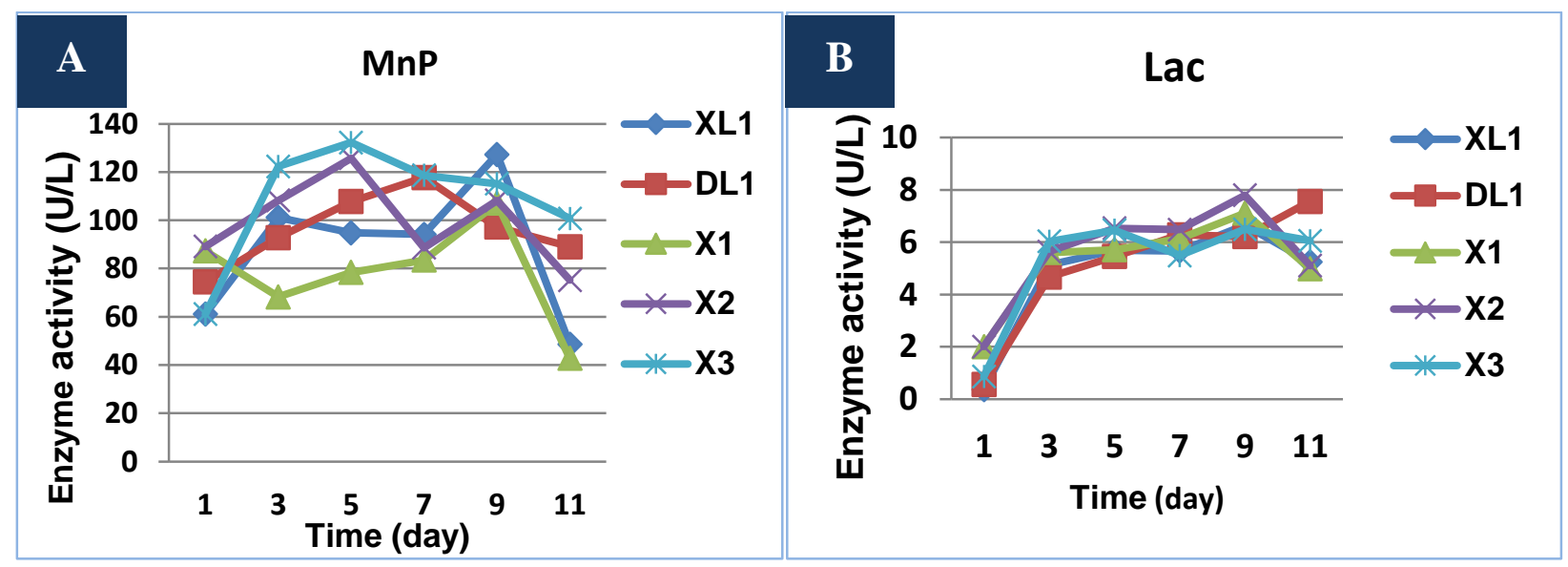

Figure 6. Impacts of culture time in $60^{\circ} \mathrm{C}$ incubation of the five strains on MnP (A) and Lac (B) activities (by quantitative assay)

The best times for the activity of $\mathrm{X} 3$ were on the $3^{\text {rd }}(122.332 \mathrm{U} / \mathrm{L}), 5^{\text {th }}(132.197 \mathrm{U} / \mathrm{L})$, and $7^{\text {th }}$ days (118.655 U/L), while in DL1, the enzyme product increased gradually and reached the maximum on the $7^{\text {th }}$ day $(117.756 \mathrm{U} / \mathrm{L})$. In addition, Lac production of the two strains X3 and DL1 was also high. On the $3^{\text {rd }}$ day, the efficacy of X3 was the highest at $6.028 \mathrm{U} / \mathrm{L}$ after increasing sharply from the $1^{\text {st }}$ day, and during the same period, the Lac products in the strain DL1 increased dramatically from the $1^{\text {st }}$ day to the $11^{\text {th }}$ day at which it obtained the highest level of $7.556 \mathrm{U} / \mathrm{L}$. Additionally, in the rest of the strains, the production of all three enzymes fluctuated throughout the experimental time.
Therefore, X3 and DL1 were selected for further investigation in the next series of studies.

\section{Effects of $p H$ values}

The two selected strains, X3 and DL1, were grown on medium with various $\mathrm{pH}$ values that ranged from 3.0 to 10.0 . The results (Table 2) displayed that the optimum $\mathrm{pH}$ range for the strongest enzyme activities of both X3 and DL1 was 3.0-8.0, suggesting that the two strains can endure low acidic $\mathrm{pH}$ values. This result was relatively similar to the research of Hariharan \& Nambisan (2012). In particular, both strains showed the highest ligninolytic system activities at $\mathrm{pH} 4.0$, in which all three enzymes had either 
Table 2. Ligninase activities of $X 3$ and $D L 1$ in different $\mathrm{pH}$ conditions

\begin{tabular}{|c|c|c|c|c|c|c|}
\hline \multirow{2}{*}{$\mathrm{pH}$ values } & \multicolumn{3}{|c|}{ X3 } & \multicolumn{3}{|c|}{ DL1 } \\
\hline & LiP & $\mathrm{MnP}$ & Lac & LiP & $\mathrm{MnP}$ & Lac \\
\hline 3.0 & ++ & ++ & +++ & ++ & ++ & ++ \\
\hline 4.0 & +++ & ++ & ++ & +++ & +++ & ++ \\
\hline 5.0 & ++ & +++ & ++ & ++ & ++ & ++ \\
\hline 6.0 & ++ & ++ & ++ & ++ & ++ & ++ \\
\hline 7.0 & ++ & ++ & ++ & ++ & ++ & ++ \\
\hline 8.0 & ++ & + & ++ & ++ & + & +++ \\
\hline 9.0 & + & + & + & + & + & + \\
\hline 10.0 & + & + & + & + & + & + \\
\hline
\end{tabular}

Note: (+) Good activity; (++) Very good activity; (+++) Excellent activity

very good or excellent activity. The best activity of $\mathrm{LiP}$ was obtained at $\mathrm{pH} 4.0$ in both strains. This $\mathrm{pH}$ also promoted an excellent activity of $\mathrm{MnP}$ in DL1, while MnP produced by X3 reached the highest efficiency at $\mathrm{pH}$ 5.0. The Lac enzyme showed the most differences in activity between two strains. $\mathrm{X} 3$ produced the highest level of Lac product at $\mathrm{pH} 3.0$, while the best Lac activity in DL1 was observed at pH 8.0.

\section{Effects of nutrient sources}

Nutrient sources such as carbohydrates and nitrogen were alternatively tested to determine the best culturing conditions for the ligninase activity of X3 and DL1. Various carbohydrate sources were examined, namely, D-glucose, Dfructose, maltose, raffinose, rhamnose, lactose, saccharose, dextrin, and starch with a concentration of $1 \%(\mathrm{w} / \mathrm{v})$. The results showed that the carbon sources significantly affected the activity of ligninolytic enzymes of both strains. D-Glucose, raffinose, lactose, and starch had the highest efficiencies in terms of enzymatic system activity in the strain X3. Of note, D-glucose promoted good activity of $\mathrm{MnP}$ and excellent activity of LiP and Lac (Table 3). Lactose, on the other hand, led to great productivity of $\mathrm{MnP}$ and Lac. Strain DL1 had the most superior responses of the ligninase system under the effects of the carbon sources D-fructose, D-glucose, raffinose, and saccharose. In particular, D-fructose was the best carbohydrate source to produce maximum activity of all three ligninase enzymes (excellent with LiP, very good with both $\mathrm{MnP}$ and Lac), while D-glucose and saccharose produced outstanding results with LiP, and raffinose led to the most effective MnP activity. Other carbon sources in this experiment illustrated declined enzyme products.

Besides carbohydrates, different nitrogen sources $\left(\mathrm{NaNO}_{3}, \mathrm{NH}_{4} \mathrm{Cl}, \mathrm{NH}_{4} \mathrm{NO}_{3},\left(\mathrm{NH}_{4}\right)_{2} \mathrm{SO}_{4}\right.$, triammonium citrate, peptone, meat extract, and yeast extract at $0.1 \%(\mathrm{w} / \mathrm{v}))$ were also assessed for their influence on ligninase activities (Table 4). Among the nitrogen sources checked, meat extract, yeast extract, $\mathrm{NH}_{4} \mathrm{Cl}$, and $\mathrm{NH}_{4} \mathrm{NO}_{3}$ showed the strongest efficacies on enzyme yield of the strain X3. X3 showed excellent LiP and $\mathrm{MnP}$ activities with the addition of meat extract to the culture environment, while yeast extract impacted both LiP and Lac impressively. In addition, $\mathrm{NH}_{4} \mathrm{Cl}$ and $\mathrm{NH}_{4} \mathrm{NO}_{3}$ led to the highest Lac production. Regarding DL1, using $\mathrm{NaNO}_{3}$, $\left(\mathrm{NH}_{4}\right)_{2} \mathrm{SO}_{4}$, triammonium citrate, peptone, and yeast extract as nitrogenous sources brought higher enzymatic yields. LiP activity had excellent production under the effects of $\mathrm{NaNO}_{3}$; while $\mathrm{MnP}$ was promoted by $\mathrm{NaNO}_{3}$, peptone, and yeast extract. The activity of Lac in DL1 was 
Table 4. Influence of different nitrogen sources on ligninase activities

\begin{tabular}{|c|c|c|c|c|c|c|}
\hline \multirow{2}{*}{ Nitrogen sources } & \multicolumn{3}{|c|}{ X3 } & \multicolumn{3}{|c|}{ DL1 } \\
\hline & LiP & $\mathrm{MnP}$ & Lac & LiP & $\mathrm{MnP}$ & Lac \\
\hline $\mathrm{NaNO}_{3}$ & + & ++ & + & +++ & ++ & + \\
\hline $\mathrm{NH}_{4} \mathrm{Cl}$ & + & + & +++ & + & + & + \\
\hline $\mathrm{NH}_{4} \mathrm{NO}_{3}$ & + & + & +++ & + & + & + \\
\hline$\left(\mathrm{NH}_{4}\right)_{2} \mathrm{SO}_{4}$ & + & + & + & + & + & +++ \\
\hline Triammonium citrate & + & + & + & + & + & +++ \\
\hline Peptone & + & ++ & + & + & ++ & +++ \\
\hline Meat extract & +++ & +++ & + & + & + & + \\
\hline Yeast extract & +++ & + & +++ & + & +++ & + \\
\hline
\end{tabular}

Note: (+) Good activity; (++) Very good activity; (+++) Excellent activity

Table 5. Biochemistry tests of the strains $X 3$ and DL1

\begin{tabular}{ccc}
\hline Biochemistry Test & X3 & DL1 \\
\hline Starch Hydrolysis & + & - \\
Cellulose Hydrolysis & + & - \\
Motility & - & - \\
Urease & + & + \\
Citrate Utilization & + & + \\
Catalase & + & + \\
\hline
\end{tabular}

excellent when subjected to $\left(\mathrm{NH}_{4}\right)_{2} \mathrm{SO}_{4}$, triammonium citrate, and peptone. Meat extract did not show a significant effect on any enzyme activity of DL1. These results were suitable with the published study of Hariharan \& Nambisan (2012).

\section{Biological characteristics of the strains X3 and DL1}

In this study, the two strains X3 and DL1 showed strong and stable enzymatic activities in various culture conditions. Several biochemistry tests were performed using these strains in order to provide more information to benefit further research. The results (Table 5) displayed that the X3 strain had some prominent features as compared to DL1, such as starch and cellulose hydrolysis activities. These abilities play a significant role in the application for agricultural residues treatment by the biopile method, especially when having the combination of ligninase activities of these strains and other microorganisms.

In addition, the data demonstrated that both strains were either aerobic or facultative aerobic because of positive catalase reactions with $\mathrm{H}_{2} \mathrm{O}_{2}$ $3 \%$, they have the capability to use citrate as a carbon source, and they have the ability to secrete urease into the environment. However, these two strains were negative in the motility test.

\section{Conclusions}

Five bacterial strains (XL1, DL1, X1, X2, and X3) that expressed ligninolytic activity were isolated from three soil samples. Among them, the X3 and DL1 strains showed strong enzymatic activity in various conditions. They were capable 
of adapting well and producing high enzymatic activity at a temperature of $60^{\circ} \mathrm{C}$, and had the ability to tolerate extremely acidic media with optimum $\mathrm{pH}$ values of 3.0 and 4.0.

Ligninase enzymes in each strain showed different activity levels when subjected to various sources of carbohydrates and nitrogen. Of which, D-glucose and yeast extract were suitable to promote most of the enzymes in the study. While the $\mathrm{X} 3$ strain can use D-glucose and lactose (carbon sources) or $\mathrm{NH}_{4} \mathrm{C}, \mathrm{NH}_{4} \mathrm{NO}_{3}$, meat extract, and yeast extract (nitrogen sources) to get great productivity of ligninolytic enzymes, peptone and $\mathrm{NaNO}_{3}$ were the most suitable sources of carbon and nitrogen, respectively, for the DL1 strain to have high ligninolytic activity. As compared to DL1, the X3 strain showed prominent characteristics regarding starch hydrolysis and cellulose hydrolysis. Both strains were capable of utilizing citrate and generating urease and catalase.

\section{References}

Chabannes M., Ruel K., Yoshinaga A., Chabbert B., Jauneau A., Joseleau J. \& Boudet A. (2001). In situ analysis of lignins in transgenic tobacco reveals a differential impact of individual transformations on the spatial patterns of lignin deposition at the cellular and subcellular levels. The Plant Journal. 28: 271-282.

Givaudan A., Effosse A., Faure D., Potier P., Bouillant M. \& Bally R. (1993). Polyphenol oxidase in Azospirillum lipoferum isolated from rice rhizosphere: Evidence for laccase activity in nonmotile strains of Azospirillum lipoferum. FEMS Microbiology Letters. 108: 205-210.

Hariharan S. \& Nambisan P. (2012). Optimization of Lignin Peroxidase, Manganese Peroxidase, and Lac Production from Ganoderma lucidum Under Solid State Fermentation of Pineapple Leaf. BioResources. 8(1): 250-271.

Kuwahara M., Glenn J. K., Morgan M. A. \& Gold M. H. (1984). Separation and characterization of two extracelluar $\mathrm{H} 2 \mathrm{O} 2$-dependent oxidases from ligninolytic cultures of Phanerochaete chrysosporium,
FEBS Letters. 169(2): 247-250.

Nigam P. S-N. \& Pandey A. (2009). Biotechnology for Agro-Industrial Residues Utilisation: Utilisation of Agro-Residues. Springer, 466 pages.

Magalhães D. B., de Carvalho M. E. A., Bon E., Neto J. S. A. \& Kling S. H. (1996). Biotechnology Techniques. Kluwer Academic Publishers. 10: 273.

Martínez A. T., Ruiz-Dueñas F. J, Martínez M. J., del Río J. C. \& Gutiérrez A. (2009). Enzymatic delignification of plant cell wall: from nature to mill. Current Opinion in Biotechnology. 20(3): 348-357.

Martins L. O., Soares C. M., Pereira M. M., Teixeira M., Costa T., Jones G. T. \& Henriques A. O. (2002). Molecular and biochemical characterization of a highly stable bacterial laccase that occurs as a structural component of the Bacillus subtilis endospore coat. Journal of Biological Chemistry. 277(21): 1884918859.

Niladevi K. N. \& Prema P. (2005). Mangrove Actinomycetes as the Source of Ligninolytic Enzymes. Actinomycetologica. 19(2): 40-47.

Papinutti V. L., Diorio L. A. \& Forchiassin F. (2003). Production of laccase and manganese peroxidase by Fomes sclerodermeus grown on wheat bran. Journal of Industrial Microbiology and Biotechnology. 30(3): 157-160.

Pasti M. B., Pometto A. L. 3rd, Nuti M. P. \& Crawford D. L. (1990). Lignin-solubilizing ability of actinomycetes isolated from termite (Termitidae) gut. Applied and Environmental Microbiology. 56(7): 2213-2218.

Ramachandra M., Crawford D. L. \& Pometto A. L. (1987). Extracellular Enzyme Activities during Lignocellulose Degradation by Streptomyces spp.: A Comparative Study of Wild-Type and Genetically Manipulated Strains. Applied and Environmental Microbiology. 53(12): 2754-2760.

Sasikumar V., Priya, Shankar C. S. \& Sekar D. S. (2014). Isolation and preliminary screening of lignin degrading microbes. Journal of Academia and Industrial Research. 3(6): 291-294.

Singh S. N. \& Tripathi R. D. (2007). Environmental Bioremediation Technologies. Springer, 520 pages.

Vicuña R. (1988). Bacterial degradation of lignin. Enzyme and Microbial Technology. 10(11): 646-655.

Wong D. W. S. (2009). Structure and action mechanism of ligninolytic enzymes. Applied Biochemistry Biotechnology. 157(2): 174-209. 